\title{
Racism in Conrad's Heart of Darkness: A Critical Investigation
}

\author{
Sonia Sharmin \\ Assistant Professor, Department of English, Islamic University, Bangladesh
}

\begin{abstract}
This paper deals with the concept of racism, which is considered as a dark chapter in the history of the world.Throughout history, racist ideology widespread throughout the world especially between blacks and white. Joseph Conrad's Heart of Darkness which is his experience in the Congo River during the 19th century dealt with the concept of racism, which was clear in this novel because of the conflicts that were between black and whites and it explained the real aims of colonialism and expansionism in Africa, which were for wealth and power. This paper shows Marlow's limitations as a narrator, his ethnocentricity and color consciousness and inability to comprehend inscrutable Africa that lead him to side with the colonizers against the Africans and how his approach is shared by Conrad as well. A bitter irony lies in the fact that the people who look apparently civilized in the novel are most savage in reality. In fact, power, jealousy and greed for ivory or money have metamorphosed them into corrupt, monstrous, brutal animal. My point of argument is that Conrad in Heart of Darkness has biasness for European colonialism, though the biasness is not so much conspicuous but ostensible, covertly and allusively maintained throughout.
\end{abstract}

\section{INTRODUCTION}

Racist ideologies and views, widespread legally and illegally, in the United States but also in Europe were deeply entrenched in the values of many societies, in their ideologies and the religions, political and cultural sides. As a general rule, racism and discrimination were used to protect the political and economic interests of those who discriminate. Racism spread throughout the world especially in the 19th century and many racist groups tried to impose their civilization and their values because they believed that they had different abilities and different characteristics, so the racist powers used different strategies or ideologies in order to put down the power of the other races making them less human. In addition, people who are treated as inferior seem to feel the need to find others over whom they can claim superiority.So, slavery, segregation Nazism and apartheid, all represent the word racism but racial discrimination and slavery were considered as the darkest sides.

In the United States and in European countries, white people considered themselves superior to darker people that created many problems in the same societies. In addition, industrialization and trade led many European countries to adopt all types of racism in order to achieve their goals ,also they competed with each other in order to get more territories abroad. So, Europeans started to adopt new ideologies that supported the white races everywhere and denied the superiority of non -white races which means black or brown ones. European's need for wealth and raw materials in the 19th century led them to search for territories in Africa or India and they started to establish themselves as great powers. Many European writers and the British in a particular took the opportunity in order to depict the world of racism and colonialism especially during the 19 century and English writers described the world of new imperialism which was caused by the British competition for trade and power.

\section{RACISM IN HEART OF DARKNESS}

Heart of Darkness is Joseph Conrad's experience in the Congo River and Joseph Conrad used Marlow as a character in order to recount his real story.The writer depicted terror because Heart of Darkness put light on the colonial era and on colonizer's ambition to power and raw materials and wealth.Joseph Conrad gave too much importance to the hypocrisy of the colonial efforts that was interested in material sides. Heart of 
Darkness gave too much importance to the pretexts of civilization which were used in order to hide the real aims of colonialism when the colonizers suggested that the real goals of colonialism were to help the black Africans who were considered as a backward people.

Many European writers in general and the British in a particular such as: Joseph Conrad, Rudyard Kipling, and E.M.Forster also Joyce Cary who tried to depict the issue of racism and imperialism through novels and poems for example Heart of Darkness by Joseph Conrad, a passage to India by E.M Forster, and The white Man's Burdens by Rudyard Kipling. So, all these works had brought the colonial world into the art of fiction. All these writers that were mentioned before gave too much importance to the issue of race, power, and economic expansion and also to the conflicts that existed between Europe and other continents on which Jonah Ruskin said:

Modern novelists -from Conrad to Lawrence

from Kipling to Orwell, from Forster to Cary

-have been preoccupied with race, with

cultural and national conflicts.

Heart of Darkness is Joseph Conrad's experience in the Congo in 1890. Joseph Conrad was a sailor and a writer in the same time. Heart of Darkness fits into the genre of colonial literature and the narrator told the story from a ship at the Thames river Joseph Conrad used Marlow as a character who recounted his experience of his time in the Congo or in Africa in the early mid of the 1890's during the colonial era. The story was one of the 19th century's novels when many European writers tried to depict the world of colonialism and imperialism of European countries in Africa and Asia.

Africa was the goal for many European nations who competed with each other to colonize more and more territories, which led to the scramble for Africa. These European countries tried to implant in the African minds who were primitive and innocent, that their presence in Africa was very important for the cause of civilizing and educating them but their actions were against the reality.

Europeans and especially during the 19th century were interested in gaining more and more resources and wealth without giving importance to how they did it which means self interest.The best reason was that Africans were treated as animals or let's say as savages or criminals because European countries believed that Africa was a dark continent where there was neither civilization nor religion.So, it can be noticed that colonialism in Africa in the 19th century based its actions on racism, racial discrimination and segregation because colonizers were interested on gaining wealth and raw materials. Heart of Darkness is a great and powerful depiction about what is said before.It was set in the Congo in the 19th century when Britain was the greatest power because it controlled more and more territories in the world and especially in Africa.

The Congo was the best example in which Joseph Conrad told his experience and it is a great example of how much the colonial power were racist because Heart of Darkness revealed the hypocrisy of the colonial missions in the Congo in particular and Africa in general. Joseph Conrad in his novel used strong images about how much colonisation damaged white coloniser's souls because of their bad treatment and greed towards black Africans. Racism in Heat of Darkness was clear from the beginning of the novel. Marlow started recounting his experience by saying to his fellows: "I do not want to bother you much with what happened to me personally."

Marlow tried to say that his trip was a strange and disturbing one because of what he had seen there and his statement worked as an alert to his fellows. Heart of Darkness gives a clear image about how the natives or the Africans were ill -treated because of colonialism and the greed of imperialism because they were treated as slaves or objects rather than human beings : 
Black figures strolled about listlessly pouring water

on the glow, whence proceeded a sound of hissing,

stream ascended in the moonlight the beaten nigger

groaned some where.

Heart of Darkness is a novel about racism and British superiority because the British believed that blacks or niggers as they called them lived without any purpose or goal because they had no civilization, no education and even no religion.In addition, they believed that black people in Congo behaved as animals and their attitudes annoyed them a lot:

It was paddled by black fellows.You could see

from afar the white of their eyeballs glistening.

They shouted, sang; their bodies streamed with

perspiration; they had faces like grotesque masksthese

chaps; but they had bone, muscle, a wild vitality,

an intense energy of movement, that was as natural and

true as the surf along their coast.

Heart of Darkness gives a clear image about black people in the Congo who were obliged to do hard works without reacting as Marlow had seen them falling down and carrying a lot of packages which were full of earth under the white master's control as a cattle of animals:

They were building a railway, six man advanced

In file, toiling up the path, they walked erect and slow,

balancing small baskets full of earth on their heads, and

kept time with their footsteps.

Heart of Darkness depicted black Africans during the 19th century who suffered from starvation and illnesses, and also suffered from the racist attitudes of imperialist powers, which took their land, their wealth and treated them as slaves.Darkness was everywhere in Joseph Conrad's Heart of Darkness and it is considered as the most powerful sign of racism and imperialism in Africa in general and Congo in particular. When Marlow went deeper and deeper into the Congo, he started to discover the greed and horror and also the abuses and hypocrisy of the imperial system and imperialists who were interested in money, land and power.

Marlow witnessed illness and humanity, people who suffered under the white empire and treated as machines. Also he described the black Congolese who were ill- treated when they were forced to do hard works and enchained at the same time to each other and this is slavery. So, blacks were forced to do hard labour especially in agriculture or in building for example rail ways because white colonizers believed that blacks were better at doing hard works than them.

Marlow faced horror and fear because he was not able to believe in what he had seen that is why his description was filled with images of darkness:

Black rags were wound round their loins and short

ends behind waggled to and frolike tails. could see every

American Research Journal of English and Literature

Page 3 
rib, the joints limbs were like knots in a rope; each had

an iron collar on his neck, and all were connected together

with a chain whose bights swung between them, rhythmically

clinking.

White agents forced the Congolese to do slave labour by means of torture that is why they could not even react, Marlow's journey can be considered as a nightmare because of what he had seen there from disease, starvation, natives who had been exploited or whipped or even killed them by millions at a time.

In the novel, there is a reference to a total denial of any civilization in Africa because Europeans believed that Africa and Africans in general were uncivilized which means backward or primitive people that is why Marlow described his trip as a journey back in time as he had said: "going up that river was like travelling back to the earliest beginning of the world." So the British adopted all types of racism in order to get what they want which led to the misuse of power that reflected the evils of colonialism.

Heart of Darkness can be seen as a story of a man who faced a number of political, moral and spiritual horrors and Congolese were treated as slaves: the white man, sometimes, tried to invent excuses to punish or torture them because they were masters and superior. In this description, Marlow insisted on the suffering of the Africans because they were alive physically but morally dead as shadows: "Black shapes crouched, lay, sat between the trees, leaning against the trunks, clinging to the earth, half coming out, half effaced within the dim light, in all the attitudes of pain, abandonment and despair."

In addition, each statement in the novel reflected the suffering of the Congolese who were forced to work under the white master's control who adopted all types of violence and racism in order to frighten, or kill the Africans. Congolese in the novel had no names; they were only dead people or let's say shadows or black shapes suffering starvation and diseases: "They were dying slowly-it was very clear. They were not enemies, they were not criminals, and they were nothing earthly now, nothing but black shadows of diseases and starvation.Lying in the greenish gloom."

Africans in Heart of Darkness were only black wild, natural shapes who lived in the jungle as a dark place like animals. In addition Joseph Conrad's Heart of Darkness explains the goals of the colonizer who used the pretext of civilization in order to get what they wish, which means wealth; ivory and money in order to develop their economy.

The British entered Africa and tried to spread their religion, their language and their civilization because they believed that it was their responsibility to spread the superiority of their civilization. In addition, they believed that their mission was to lighten the Dark Continent Africa and they thought that blacks had no sense of personality that is why they need the Europeans help.

British and European culture was undoubtedly far more virulently racist than it is today, and to expect a white writer educated in that culture to fail to hold some type of racial bias is no more plausible than to expect a writer living and working next to an oil refinery to not smell a bit like petroleum. It's difficult to notice an everyday, background evil if everyone presents it as normal. Heart of Darkness is a fictionalized chronicle of what the protagonist (and author) recognized as a horrific time in human history and is a vivid critique of it. However, Conrad's narrator relates the atrocities committed against the people of Africa without ever fully conveying the ultimate bitter truth of colonialism: that those inhuman horrors were made possible because even people who did not directly profit from Africa's exploitation (and who otherwise might have protested or worked against it) bought into racist political and nationalist narratives. 
However, the British acts were against their missions of civilization because their presence, was not for the benefit of the Africans but their interest was on natural resources especially ivory. Kurtz in Heart of Darkness reflected what is said before thanks to Marlow's description. Kurtz who was the chief of the inner station in Congo, was a man of great talent who intended to be the man of virtue..His goal before establishing himself was to civilize and help the natives of Africa, he was sent to the Congo for the purpose of bringing morals and European enlightenment to the colonists in which Africa, was considered as a savage and mysterious continent.

However, Kurtz was transformed from a man of European enlightenment and morals to an evil or monster because of his greed, and he became inhuman. In fact, Kurtz reflected the British colonialists who saw themselves as a people of great ideas just as civilized ones, but their civilization abused the Africans and took their raw materials and their wealth. Kurtz turned out to be the greatest monster of all because he had forgotten his morals and his mission of civilization and he became a thief who took the wealth of the natives by force rather than trading for it.

In addition, Kurtz misused his values which became power and he started to treat the natives as animals rather than people. He obliged blacks to work for his benefit, also they were forced to carry heavy baskets under his control.In addition, and Kurtz established himself as a god for the natives which means that he was just an evil or monster because he took the dark situation of the Congolese in order to establish himself. Kurtz, in Heart of Darkness represented the British colonialism and imperialism, which claimed to civilize and educate the natives but their actions, showed the opposite because they were interested in wealth not in people.

There is no doubt of it that Conrad's Heart of Darkness (1899) is a critical document of European Colonialism worldwide in general, Africa in particular. It is one of the very few texts that present an enquiry into the nature of colonialism and a self-conscious reluctant denunciation of it as well as Conrad's own partial attitude towards Colonialism. At the same time, it shows how Colonizers in the name of civilizing African indulged in trade and sent ivory back to Europe (very familiar scene of the blue cultivation in Indian sub-continent during the British period)- Conrad and his protagonist, Marlow demonstrate their superiority over native people. Thus Conrad's critique of colonialism in Heat of Darkness is undermined by his racist assumptions and ambivalence about the colonizer's mission in Africa. In this paper, it will be shown how Conrad's racist, xenophobic, ethnocentric and jingoistic feeling pervade the whole novel, though there is no sign of human feeling for the colonized and oppressed Africans.

Before my discussion on the issue of racism let me focus in brief the western idea about Africa. Black Africans are regarded as uncivilized, primitive, savage, brutal, violent and lascivious. Shakespeare's Othello fails to adjust in the white Community because he is a black moor. The white Iago sees him as 'barbary horse'. Caliban is dispossessed and enslaved since he is black and gullible and his mother African (Algier) ancestry.19 $9^{\text {th }}$ century German philosopher G.W.F. Hegel believes that God's plan for humanity should be established through Europe. Daniel Defoe in Robinson Crusoe depicts black people's cannibalistic activity in a remote island and shows how Crusoe like a colonial master teaches the uncivilized Friday his own (Crusoe's) language. This sort of idea encouraged European conquest of Africa and other undeveloped regions. Europeans think that the "Negro is the European in embryo" (Schweitzer 38). One of the European missionaries Albert Schweitzer who once worked in Africa said, "The African is indeed my brother, but my junior brother." D.H. Lawrence is held in high esteem as one of the pioneers of $20^{\text {th }}$ century literature, but his idea also goes on the brink of racism. In his Aaron's Rod he made the proclaim "I cannot do with folk who teem by the billion, like the Chinese, Orientals altogether. Only vermin teem by the billion. Highest types breed slower.

So it is very obvious that non-Europeans and Africans are always portrayed by the pejorative terms. That is why we will not be surprised to see Conrad describing Africans in an obnoxious way, though time to time he shows his sympathy for the native Africans.

American Research Journal of English and Literature

Page 5 
Conrad's portrayal of Kurtiz's African mistress reveals his racial bias and prejudice His line is "A wild and gorgeous apparition of a woman (100). She is compared to a ghost. Conrad criticizes the dresses of the woman. Marlow depicts her, "She is treading the earth proudly, with a sight jingle and flash of barbarous ornaments, her hair was done in the shape of a hamlet innumerable necklaces of glass beads or her neck; bizarre things charms, gifts of a witch men (100-101). She is again described, "She was savaged and superb, wild-eyed and magnificent (101)". Bestowal of human expression to the one and the withholding of it from the other" (119).

Conrad and his protagonist, Marlow display their racist attitude by referring some African as cannibal. It is highly contentious whether there was any cannibalism in Africa in the $17^{\text {th }}$ or $18^{\text {th }}$ century or $19^{\text {th }}$ century. But in the Eurocentric discourse it is widely acknowledged that cannibalism was prevalent in Africa at that time. Marlow says about cannibal crew: "Fine fellows- cannibals-in their place." Marlow also praises them for their restrains. He said that these cannibals were of a better type. They did not eat human flesh, though they were hungry. This sort of condescending praise by Marlow is totally unwarranted and undesirable. Through this, Conrad or Marlow wants to establish their racial superiority over the black Africans. Later when Marlow's helmsman is killed in the ambush, Marlow has to quickly shove his body overboard in order to prevent a cannibalistic orgy on board the ship. It suggests that though Marlow praises cannibals, in his inner mind he knows these cannibals can take human flesh any time. In this way, Africans are systematically abused, degraded and dehumanized. It is argued that one of the reasons for cannibalism to be prevalent in Africa in the western discourse was to justify Africans to be primitive and thus they had to be colonized and civilized.

Marlow or Conrad charges Africans with devil worshipping. In this way Marlow again tries to express their supremacy over the Africans. But this devil worshipping is also blown out of proportion. Conrad is not oblivious of the fact that this was not confined to Africa alone. Even it was pervasive in England and America. Nathaniel Hawthorne's The Scarlet Letter and Young Goodman Brown are striking examples of how devil worshipping was going on in these counties. Human sacrifice is another propaganda that is initiated in this text by Marlow.

Conrad's racism goes one step further when his protagonist Marlow makes some abhorrent remarks about Africa and its people. Marlow says. "We were wanderers on a prehistoric earth" Africa is told to be a primitive country. Marlow does not pause here. He now maligns African people. He says "The prehistoric man was cursing us, praying to us, welcoming us-who could tell?" Marlow at this point defends Africans by saying "No, they were not inhuman". But this particular sentence has some problem. What is Marlow's real purpose when human beings are being told that they were not inhuman? Actually Conrad does not like to regard them as human beings. Africans have been thoroughly depersonalized here.

Animal imagery is also attached to the native Africans. Marlow says "They howled, and leaped, and spun, and made horrid faces." Here one can raise a very pertinent question about Conrad. Is he honest in his projection of African people? Do African people howl when they see new people? There is a systematic abuse of African people in Heart of Darkness.

Black people or Negroes are supposed to be subhuman and knee-bending races. Marlow's ideal almost goes like that. He describes his fireman. "And between whiles I had to look after the savage who was my fireman. He was an improved specimen to look at him was edifying as seeing a dog in a parody of breeches and feather hat, walking on his hind legs. A few months of training had done for that really fine chap". Here again an African is deprived of full human quality. One can have a knee-jerk reaction to see a normal human being compared to a dog. Again and again 'savage', 'nigger', 'wild', and 'cannibal' are used for African people. We can assert that this is a deliberate attempt of Conrad to blacken African people.

The idea of civilizing mission is also broadly hinted here. This helmsman can be trained by a European and then he can be turned into a fine human being. Without being educated or trained he will remain 'savage'. Marlow's cultural hegemony or racial superiority is understandable here. 
Africans also cannot be relative of Europeans. They (Europeans) display their snobbishness and arrogance. Marlow fails to recognize African helmsman to be his relative. At best Marlow can have "remote" or "distant kinship" with a black people. In the same way the Congo River is a symbol of ugliness, vileness and restlessness. The Thames appears to be superior to the Congo. It is very natural to Conrad or Marlow that a European river will be peaceful whereas an African river will be violent. This sort of discrimination and negative treatment of Africans have upset Chinua Achebe greatly. And he is compelled to brand Conrad as "a thoroughgoing racist."

Some critics are showing some interesting similarity between Darwin and Conrad. I mean Conrad is influenced by Darwin's philosophy "The Theory of Species". Darwin says in his book. "The main conclusion arrived at in this work namely that man is descended from some lowly organized form, will, I regret to think, be highly distressful to many. But there can hardly be a doubt that we are descended from the barbarian." $19^{\text {th }}$ century readers find no difference between barbarian and savage. Barbarian is the other to the civilized Europe. In that case it is obvious that Conrad's Marlow will affirm their superiority.

Conrad's harshest condemnation of economic colonialism is fully revealed through Kurtz. But kurtz's character can be interpreted in another way. This European goes to Africa and becomes hero or leader among the natives. The stereotyping idea that European will always be in the leading position has been established here. Lord Jim is Conrad's another novel where we get the same sort of idea. Jim is the central character who also happens to be a white European goes to a distant Malay island and becomes 'Tuan Jim' there. He is a demi-god and savior to the natives like Kurtz.

Conrad in the text shows that Kurtz's mixing with the natives has made him barbaric. After witnessing their superstitious rites for a long time he himself falls under their influence and returns to a state of savagery, barbarism and primitivism. He starts identifying himself with the savages and takes part in their customs and ceremonies. He presides over midnight dances. It concludes with "unspeakable rites". What does Conrad want to say here? Is he saying that African natives are evil and indulging in satanic practices? So his idea is if a civilized man goes and mixes with those people, he will be corrupt instantly. Conrad's depiction of degeneration of African natives is very clear. They are also shown as inferior race. This idea is similar to that of Thomas Jefferson. This third American president was against race mixture of black and white. He also argued that this distinction between white and black has been fixed by God. Race mixture would also create bitterness between two races.

One cannot be made corrupt if does not want to. Kurtz is himself responsible for his having recourse to barbarism. Marlow suggests that Kurtz's urbanization is a symbol of his depravity. Indian critic Frances B. Singh makes an apt comment here. She says "From the little we see of Kurtz's followers, thought there is nothing to suggest that they are depraved. Rather they appear as proactive simple and unselfconscious-far better specimen of humanity than the white people of Hear of Darkness.

Africans in the novel is some what taken as ambiguous. Africa is (looked upon) as Dark Continent but its antithesis Europe is always Good and auspicious. A Bakhtinian critic in "A Practical Introduction to Literacy Theory and Criticism" by Keith Brooker says "Probably the most important opposition initiated in the text is that between Europe and Africa. Marlow consistently figure Europe as 'here' while portraying Africa as distant, dark and mysterious. Europe is also treated as the focus of contemporaneity, while African is consistently described as ancient, even primeval (228)". Edward Said in Culture and Imperialism also writes "... and of European geographical centrality is buttressed by a cultural discourse relegating and confining the non-European to a secondary racial, cultural, ontological status (70).

Marlow's European racist stereotypes about Africa are abundantly clear here. They are found as 'black shadows', 'moribund shapes', 'bundle of actuate angles'. Their faces are like 'grotesque masks'. In a number of letters Conrad insists that Heart of Darkness and Lord Jim should be read together. So in Lord Jim also we get proof of Conrad's racist view. Non-Westerners are regarded as 'hyaenas', 'cattle' etc. 
Africans have been undermined and belittled horribly by Marlow and they have not been given any voice. They are not allowed to speak. Europeans speak for them like Marx's idea that they (Eastern or African) cannot represent themselves, they must be represented. An African can only have "a violent babble of uncouth sounds" or they "exchanged short grunting phrases". They are made unable to express themselves properly. Who knows, Marlow might also teach them language.

Marlow is very proud of European people's competence or skill. It is desirable to him that people of superior race will have efficiency and neatness in their work. Romans earlier conquered Britain but Marlow condemns them because of their lack of efficiency. He says "What saves us is efficiency". On the other hand, Africans are not praised to be efficient. Rather they are disturber of peace. Chief accountant starts heating 'savages' who talk nosily outside his office that makes him incapable of doing his work efficiently.

\section{CONCLUSION}

Through our above detailed discussion we see Conrad's Hear of Darkness is full of racism. From the very beginning to the end, Africans are dehumanized, depersonalized, demoralized and marginalized. They are presented in a very crude, offensive, objectionable and controversial manner. Conrad and Marlow are not different. Conrad's narrator Marlow enjoys his full confidence. Undoubtedly in this text Conrad registers his contempt, scorn and venom for European imperialism in Africa but Conrad does not assert that this should 'end so that natives can lead lives free from European domination. Europeans' racial superiority has been explicitly depicted in Hear of Darkness.

\section{REFERENCES}

1. Achebe, Chinua, "An Image of Africa: Racism on Conrad's Hear of Darkness."

2. Brooker, M. Keith. "A Practical Introduction to Literary Theory and Criticism." Longman Publishers: New York, 1996.

3. Conrad, Joseph. Lord Jim. Wordsworth Edition Limited Hertford shire, 1993.

4. Conrad, Joseph. Heart of Darkness. Penguin Books: London, 1973.

5. Said, W. Edward. Culture and Imperialism. Vintage: London, 1993.

6. Singh, B. Frances. "The Cannibalistic Bias of Heart of Darkness.” Norton Critical Edition, New York: 1998.

7. Fothergill, Anthony. Heart of Darkness. Open University Press, Buckingham, 2003.

Citation: Sonia Sharmin, "Racism in Conrad's Heart of Darkness: A Critical Investigation" American Research Journal of English and Literature, vol 4, no. 1, 2018, pp. 1-8.

Copyright (C) 2018 Sonia Sharmin, This is an open access article distributed under the Creative Commons Attribution License, which permits unrestricted use, distribution, and reproduction in any medium, provided the original work is properly cited. 